\title{
HOST PLANT PREFERENCE OF THE MELON LADYBIRD BETTLE Epilachna chrysomelina (F.) (COLEOPTERA: COCCINELLIDAE) ON DIFFERENT CUCURBIT VEGETABLES IN MANSOURA REGION. \\ Awadalla, S. S.; Horia A. Abd-Wahab. ; N. F. Abd El-Baky ${ }^{*}$ and Shymaa S. Abdel-salam \\ * Economic Entomology Dept., Fac. Agric., Mans. Univ. \\ ** Plant Protection Inst., Agric. Res. Centre, Dokki , Giza.
}

\begin{abstract}
Field experiments were carried out during 2009 and 2010 seasons to study the effect of four cucurbit crops ( squash, cucumber, snake cucumber, watermelon ) during two plantations (Summer and Late summer plantation ) on the population density of Epilachna chrysomelina $F$. The obtained results revealed that, snake cucumber plant harboured the highest average number of eggs $(59.1 \pm 4.9$ and $63.3 \pm$ 5.2 eggs $/ \mathrm{m}^{2}$ ) in late summer plantation during the two seasons, respectively. On the other hand, cucumber plants harboured the lowest average number of eggs (18.2 \pm 3.0 and $23.4 \pm 3.5$ eggs $/ \mathrm{m}^{2}$ ) in summer plantation 2009 season and late summer plantation in 2010 season, respectively. Moreover, there were a highly significant differences between the number of egg - laying on different cucurbit plants during the two seasons in the two plantations. Meanwhile, it can noticed that, the melon ladybird beetle females preferred snake cucumber to egg-laying followed by squash, watermelon and cucumber revealed the lowest cucurbit plant to the insect female to egg-laying preference.

The obtained results showed that, snake cucumber plant harboured the highest average number of larvae $\left(35.7 \pm 4.0\right.$ and $44.5 \pm 4.5$ larvae $\left./ \mathrm{m}^{2}\right)$ in late summer plantation during 2009 and 2010 seasons, respectively. On the other hand, cucumber plants harboured the lowest average number of larvae (13.5 \pm 2.6 and $14.2 \pm 2.9$ larvae $/ \mathrm{m}^{2}$ ) in summer plantation 2009 and late summer plantation in 2010 season, respectively. Moreover, there were highly significant differences between the number of larvae on different cucurbit plants during the two seasons in the two plantations. Meanwhile, it can noticed that, the melon ladybird beetle E. Chrysomelina preferred snake cucumber to larvae followed by squash, watermelon and Cucumber exhibited the lowest cucurbit plant to the insect larvae rearing.

The results indicated that, snake cucumber plant harboured the highest average number of the adult $\left(12.5 \pm 2.5\right.$ and $21.1 \pm 3.6$ individuals $\left./ \mathrm{m}^{2}\right)$ in late summer plantation in the first and second seasons, respectively. On the other hand, cucumber plants harbored the lowest average number of adult $(4.9 \pm 1.8$ and $6.1 \pm 2.1$ individuals $/ \mathrm{m}^{2}$ ) in late summer plantation in the first and second seasons, respectively. Moreover, there were highly significant differences between the numbers of adults on different cucurbit plants during the two seasons in the two plantations. Meanwhile, it can noticed that, the melon ladybird beetle E. Chrysomelina adults preferred snake cucumber followed by squash, watermelon and cucumber revealed the lowest cucurbit plant preference to the insect adult.

The obtained results indicated that, late summer plantation harboured the highest average number of eggs, larvae and adults of the insect pest on all cucurbit host plants. Moreover, the second season 2010 exhibited the highest average number of the insect population on the tested cucurbit host plants.
\end{abstract}




\section{INTRODUCTION}

The melon ladybird beetle, Epilachna chrysomelina F.(coleoptera : coccinellidae) is considered a serious pest of cucurbit plants in Egypt (Gameel 2004 , Gameel and Abdel-Gaid 2007and Sayed and Gameel 2008 ) and is widely distributed (El-Seady,1978, Ali and El- Seady,1986 and AbdelMoniem et al.,2004). Both larvae and adults cause great damage in a short time. Its feeding habits are phytophagous and injurious. It feeds on leaves, flowers and fruits of their host plants, belonging mainly to the family cucurbitaceae. The damage to the leaves reduces the vegetative production of the host-plant, but sometimes flours or even fruits are also destroyed. Leaves are skolotonized by feeding on the epiderm of one side, whereas that of the other side remains intact. Badly damaged leaves shrive and dry up. ( Ali and El-saeady 1981 and 1986). The effect of different host plant on the induction of diapause, survival rate and emergence from diapause was determined in laboratory studies. Diapause induction was influenced by marked climatic changes and type of food-plant. ( Ali and El-Saeady 1983) .

Three essential components of pest management programs are host consummation, host plant preference of the insect pest and its developmental rate. Economic injury levels have been proposed by using feeding rates of coleopterous insect pests (Lal, 1990; Hirano, 1993, Khan, et al, 2000, Beyene, 2007 and Sayed and Gameel 2008).

The present study aimed to throw the light on the host plant preference of the insect pest on different cucurbit vegetables in Mansoura region to serve as a basis for the use of these informations in integrate pest management programs.

\section{MATERIALS AND METHODS}

Field experiments were conducted at the Experimental Research station, Faculty of Agriculture, Mansoura University, $1 / 4$ feddan were cultivated with cucurbit cultivars Squash, Cucumber, Snake cucumber and Watermelon. Each cultivar was planted in five replicates (each one was $50 \mathrm{~m}^{2}$ ) during two planting dates, the summer plantation (June plantation) on the beginning of June and the second late summer plantation (August plantation) during beginning of August .in the two successive seasons 2009 and 2010

The conventional cultural practices were used and no chemical pesticides were applied during the present study periods. Simple Square wooden $(1 \times 1 \mathrm{~m})$ was used as standard sample size. All stages of the insect pest (eggs- larvae- pupa and adults) were counted directly on the plants in a set of four square wires (one sample $=1 \mathrm{~m}^{2}$ ) according to (El-saeady, 1978 and Gameel and Abdel-Gaid 2007). Samples were taken at random weekly from each plot and continued from the vegetative stage up to the ripening stage of the plants. the number of the insect stages (eggs, larvae, pupae and adults) on the four cucurbit plants ( Squash, Cucumber, Snake cucumber and Watermelon ) were counted weekly during the two successive seasons 2009 and 2010 in Mansoura region. Moreover, the host plant preference for female 
egg-laying, larvae reared and adults were also done. Statistical analysis was carried out by using One Way ANOVA.

\section{RESULTS AND DISCUSSION}

\section{${ }^{* *}$ Host plant preference for female egg-laying.}

Data represented in Table (1) indicated that, the highest average number of egg-laying recorded on snake cucumber during two successive seasons as well as two plantation followed by squash and watermelon, while the lowest average number of egg - laying recorded on cucumber plants during summer plantation or late summer plantation. Meanwhile, the cucurbit plants in summer plantation in the two seasons recorded the lowest average number of eggs laid.

Table (1): Host Plant preference for egg - laying by E. chrysomelina females on different cucurbit plants during 2009 and 2010 seasons in Mansoura region.

\begin{tabular}{|l|c|c|c|c|}
\hline \multirow{2}{*}{ Cucurbit Plants } & \multicolumn{3}{|c|}{ Average number of egg laying / $\mathbf{~}^{2}$} \\
\cline { 2 - 5 } & \multicolumn{2}{|c|}{ Season 2009 } & \multicolumn{2}{c|}{ Season 2010 } \\
\cline { 2 - 5 } & $\begin{array}{c}\text { Summer } \\
\text { Plant }\end{array}$ & $\begin{array}{c}\text { Late Summer } \\
\text { Plantation }\end{array}$ & $\begin{array}{c}\text { Summer } \\
\text { Plant }\end{array}$ & $\begin{array}{c}\text { Late Summer } \\
\text { Plantation }\end{array}$ \\
\hline Squash & $35.4 \pm 3.9 \mathrm{~b}^{*}$ & $40.1 \pm 4.2 \mathrm{~b}$ & $44.4 \pm 4.1 \mathrm{~b}$ & $52.7 \pm 4.9 \mathrm{~b}$ \\
Cucumber & $18.2 \pm 3.0 \mathrm{~d}$ & $20.1 \pm 3.3 \mathrm{~d}$ & $24.5 \pm 3.3 \mathrm{~d}$ & $23.4 \pm 3.5 \mathrm{~d}$ \\
Snake Cucumber & $49.8 \pm 4.5 \mathrm{a}$ & $59.1 \pm 4.9 \mathrm{a}$ & $55.4 \pm 4.6 \mathrm{a}$ & $63.3 \pm 5.2 \mathrm{a}$ \\
Watermelon & $26.7 \pm 3.6 \mathrm{c}$ & $23.7 \pm 3.5 \mathrm{c}$ & $33.9 \pm 3.7 \mathrm{c}$ & $28.9 \pm 3.9 \mathrm{c}$ \\
\hline
\end{tabular}

*Means followed by the same litter in each column are not significantly different at $1 \%$ level of the probability (One Way ANOVA).

As a conclusion, data in Table (1) revealed that, snake cucumber plant harboured the highest average number of eggs $(59.1 \pm 4.9$ and $63.3 \pm 5.2$ eggs $/ \mathrm{m}^{2}$ ) in late summer plantation during the two seasons, respectively. On the other hand, cucumber plants harboured the lowest average number of eggs $\left(18.2 \pm 3.0\right.$ and $23.4 \pm 3.5$ eggs $\left./ \mathrm{m}^{2}\right)$ in summer plantation 2009 season and late summer plantation in 2010 season, respectively. Moreover, there were a highly significant differences between the number of egg - laying on different cucurbit plants during the two seasons in the two plantations. Meanwhile, it can noticed that, the melon ladybird beetle females preferred snake cucumber to egg-laying followed by squash, watermelon and cucumber revealed the lowest cucurbit plant to the insect female to egglaying preference.

** Host plant preference for larvae rearing:-

Data arranged in Table (2) showed that, the highest average number of insect larvae recorded on snake cucumber during two successive seasons as well as two plantations followed by squash and watermelon, On the other hand, the lowest average number of insect larvae recorded on cucumber plants during summer plantation or late summer plantation in the two successive seasons.

Moreover, the cucurbit plants during the second season 2010 harboured, the highest average number of insect larvae in both summer plantation and late summer plantation. 
Awadalla, S. S. et al.

Table (2): Host Plant preference for larval stage of E.chrysomelina on different cucurbit plants during 2009 and 2010 seasons in Mansoura region.

\begin{tabular}{|l|c|c|c|c|}
\hline \multirow{2}{*}{ Cucurbit Plants } & \multicolumn{4}{|c|}{ Average number of larvae / $\mathbf{m}^{2}$} \\
\cline { 2 - 5 } & \multicolumn{3}{|c|}{ Season 2009 } & \multicolumn{2}{c|}{ Season 2010 } \\
\cline { 2 - 6 } & Summer Plant & $\begin{array}{c}\text { Late Summer } \\
\text { Plantation }\end{array}$ & $\begin{array}{c}\text { Summer } \\
\text { Plant }\end{array}$ & $\begin{array}{c}\text { Late Summer } \\
\text { Plantation }\end{array}$ \\
\hline Squash & $21.9 \pm 3.1 \mathrm{~b}^{*}$ & $26.2 \pm 3.7 \mathrm{~b}$ & $31.3 \pm 3.8 \mathrm{~b}$ & $33.5 \pm 3.9 \mathrm{~b}$ \\
Cucumber & $13.5 \pm 2.6 \mathrm{~d}$ & $13.7 \pm 2.7 \mathrm{~d}$ & $17.2 \pm 2.8 \mathrm{~d}$ & $14.2 \pm 2.9 \mathrm{~d}$ \\
Snake Cucumber & $27.9 \pm 3.4 \mathrm{a}$ & $35.7 \pm 4.0 \mathrm{a}$ & $42.2 \pm 4.2 \mathrm{a}$ & $44.5 \pm 4.5 \mathrm{a}$ \\
Watermelon & $18.8 \pm 3.1 \mathrm{c}$ & $15.9 \pm 3.1 \mathrm{c}$ & $23.5 \pm 3.4 \mathrm{c}$ & $23.5 \pm 3.4 \mathrm{c}$ \\
\hline
\end{tabular}

${ }^{*}$ Means followed by the same litter in each column are not significantly different at $1 \%$ level of the probability (One Way ANOVA).

As a conclusion, date in Table (2) revealed that, snake cucumber plant harbored the highest average number of larvae $(35.7 \pm 4.0$ and $44.5 \pm$ 4.5 larvae $/ \mathrm{m}^{2}$ ) in late summer plantation during 2009 and 2010 seasons, respectively. On the other hand, cucumber plants harbored the lowest average number of larvae (13.5 \pm 2.6 and $14.2 \pm 2.9$ larvae $\left./ \mathrm{m}^{2}\right)$ in summer plantation 2009 and late summer plantation in 2010 season, respectively. Moreover, there were highly significant differences between the number of larvae on different cucurbit plants during the two seasons and the two plantations. Meanwhile, it can noticed that, the melon ladybird beetle $E$. Chrysomelina preferred snake cucumber to larvae followed by squash, watermelon and cucumber exhibited the lowest cucurbit plant to the insect larvae rearing .

** Host Plant Preference for adults:-

Data represented in Table (3) showed that, the highest average number of adults recorded on snake cucumber during two successive seasons as well as two plantations followed by squash and watermelon, On the other hand, the lowest average number of adults recorded on cucumber plants during summer plantation or late summer plantation. in the two successive seasons.

Moreover, the cucurbit plants during the second season 2010 harboured, the highest average number of adults in both summer plantation and late summer plantation.

As a conclusion, date in Table (3) revealed that, snake cucumber plant harboured the highest average number of the adult $(12.5 \pm 2.5$ and $21.1 \pm 3.6$ individuals $/ \mathrm{m}^{2}$ ) in late summer plantation 2009 and 2010 seasons, respectively. On the other hand, cucumber plants harbored the lowest average number of adult $\left(4.9 \pm 1.8\right.$ and $6.1 \pm 2.1$ individuals $\left./ \mathrm{m}^{2}\right)$ in late summer plantation in the first and second seasons, respectively. Moreover, there were highly significant differences between the number of adults on different cucurbit plants during the two seasons and the two plantations. Meanwhile, it can noticed that, the melon ladybird beetle E. Chrysomelina adults preferred snake cucumber followed by squash, watermelon and cucumber revealed the lowest cucurbit plant preference to the insect adults. 
Table (3): Host Plant preference for E. chrysomelina adult on different cucurbit plants during 2009 and 2010 seasons in Mansoura region.

\begin{tabular}{|l|c|c|c|c|}
\hline \multirow{2}{*}{ Cucurbit Plants } & \multicolumn{4}{|c|}{ Average number of adults / $\mathbf{m}^{2}$} \\
\cline { 2 - 5 } & \multicolumn{2}{|c|}{ Season 2009 } & \multicolumn{2}{c|}{ Season 2010 } \\
\cline { 2 - 5 } & Summer Plant & $\begin{array}{c}\text { Late Summer } \\
\text { Plantation }\end{array}$ & Summer Plant & $\begin{array}{c}\text { Late Summer } \\
\text { Plantation }\end{array}$ \\
\hline Squash & $10.5 \pm 2.3 \mathrm{~b}^{\star}$ & $11.4 \pm 2.3 \mathrm{~b}$ & $14.6 \pm 3.2 \mathrm{~b}$ & $16.6 \pm 2.8 \mathrm{~b}$ \\
Cucumber & $5.8 \pm 2.1 \mathrm{c}$ & $4.9 \pm 1.8 \mathrm{~d}$ & $7.4 \pm 2.1 \mathrm{~d}$ & $6.1 \pm 2.1 \mathrm{~d}$ \\
Snake Cucumber & $12.2 \pm 2.1 \mathrm{a}$ & $12.5 \pm 2.5 \mathrm{a}$ & $20.2 \pm 3.3 \mathrm{a}$ & $21.1 \pm 3.6 \mathrm{a}$ \\
Watermelon & $10.4 \pm 2.3 \mathrm{~b}$ & $6.5 \pm 2.2 \mathrm{c}$ & $12.6 \pm 2.8 \mathrm{c}$ & $12.6 \pm 2.6 \mathrm{c}$ \\
\hline
\end{tabular}

${ }^{*}$ Means followed by the same litter in each column are not significantly different at $1 \%$ level of the probability (One Way ANOVA).

These results are in agreement with those of El-Saeady, 1978 found that the generation period of $E$. Chrysomelina was usually shorter in case of feeding on snake cucumber than feeding on other experimental and cucumber was the least susceptible cucurbit crop to the infestation with $E$. Chrysomelina under field conditions. This indicates the presence of some sort of resistance as recorded by Knipling (1979) who mentioned that resistance to insects is classified into three categories: non preference, antibiosis and tolerance. Shukla and Upadhyay (1983) recorded that light had little influence on the attraction of the coccinellid to its host plants; it was thought that chemical stimuli were involved. Meanwhile, Wilson (1986) found that the development of the first instar larvae of E. Chrysomelina richards was delayed by the leaf hairs on pumpkin leaves, which prevented them from reaching the leaf surface to feed the end first instar larvae developed faster on leaves rich in nitrogen

\section{REFERENCES}

Abdel-Moniem, A. S. H., Gomaa, A. A., Dimetry, N. Z. T. Wetzel and C. Volkmar. (2004). Laboratory evaluation of certain compounds against the melon ladybird, Epilachna chrysomelina (F.) attacking cucurbit plants.Arch. phytopathol. and plant protection. 37:71-81.

Ali, M. A and A. A. El-Saeady (1981). Influence of temperature, photoperiod and host-plant on the bionomics of the melon ladybird Epilachna chrysomelina (F.) (Coleoptera: Coccinellidae). Z.ang.Ent. 91(3): 256262.

Ali,M.A and A.A El-Saeady(1983): Studies on food consumption and host selection of the melon ladybird beetle Epilachna chrysomelina ( $F$.) (Coleoptera: Coccinellidae). Agric.-Res.-Rev. 61(1): 149-16.

Ali, M. A. and A. A. El-Saeady (1986). Phenology and population dynamics of the melon ladybird beetle Epilachna chrysomelina ( $F$.) in Egypt (Coleoptera: Coccinellidae). Agric. Res. Rev. 61(1): 179-191.

Beyene, Y. (2007). Ecology and management of Tef epilachna (Chnootriba similes) (Thunberg), Coleoptera, Coccinellidae) in Ethiopia. (Philosophiae) PH. D. Thesis, (11) 
El-Saeady, A. A (1978). Ecological and physiological studies on melon ladybird beetle Epilachna chrysomelina (F.) (Coleoptera: Coccinellidae). PH. D. Thesis, Fac. Of Agric., Al-Azhar Univ., 146 pp.

Gameel, S. M. M. (2004). Eco-Biological studies on the black melon bug, Coridius (Aspongopus) viduatus F. ( Hemiptera:pentatomidae) in the new vally . ph. D. Thesis, Fac. Of Agric., Assuit Univ., 209 pp.

Gameel, S.M.M. and M.A Abdel- Gaid (2007). Realative susceptibility of three cucurbit vegetables to the infestation Epilachna chrysomelina (f.) (Coleoptera: Coccinellidae) at the New Vally - Egypt The $1^{\text {st }}$ International conference on desert cutivation. 27-29 March, Minia Univ. 85-90.

Hirano, K. (1993). Population dynamics of a phytophagous lady-beetle, Epilachna vigintioctopunctata (Fabricius) (Coleoptera: Coccinellidae), living in spatio-temporally heterogeneous habitats II. Seasonal changes in adult movement and spatial distribution of the population. Appl. Entomol. Zool. 28 (2): 131-140.

Khan, M. H.; Islam, B. N.; Rahman, A. K. M. M.; Rahman, M. L (2000). Life table and the rate of food consumption of epilachna beetle, Epilachna dodecastigma (Wied.) on different host plant species in laboratory condition .Bangladesh J. Entomol. 10 (2): 63-70.

Knipling, E. F. (1979). The basic principles of insect population suppression and management. USDA. Agric-Handbook.51pp.

Lal, O. P (1990) Host preference of Epilachna ocellata (Redt). (Coccinellidae: Coleoptera) among different vegetable crops .J. Entomol.Res.14(1):3943.

Sayed, A. A. and S. M. M. Gameel (2008). Effect of some vegetable cucurbit crops and seasonal plantation on the population densities of Epilachna chrysomelina (f.) (Coleoptera: Coccinellidae) at the New Vally - Egypt. Egyptian J.Agric. Res. 86(3):1053-1060

Shukla, G. S. and V. B. Upadhyay (1983). Effect of ecological factors food preference of Epilachna dodecastigma (Coleoptera:Coccinellidae) on vegetable plants.(i) light. J. Adv. Zool. 1983,4(1):49-54.

Wilson, L. J. (1986). Movement abd feeding patterns of Epilachna cucurbitae Richards (Coleoptera: Coccinellidae) on Pumpkin and zucchini plants Aust J Ecol. 11(1):55-62. 
تفضـيل العوائلـل النباتيـة لحشـرة خنفســاء القثـاء على محاصسيل خضـرمختلفة مـن

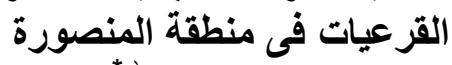

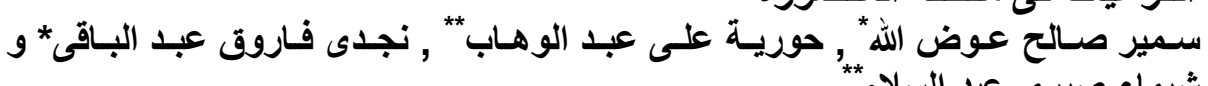

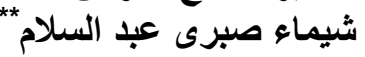

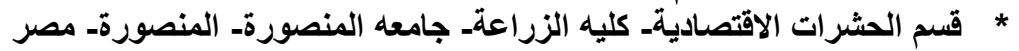

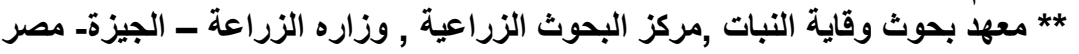

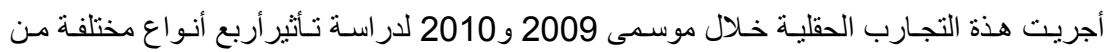

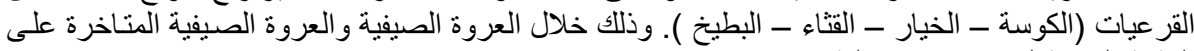
الكثافة العددية لحشرة خنفساء القتاء.

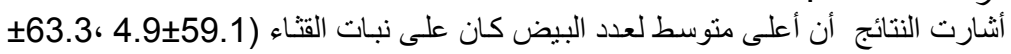

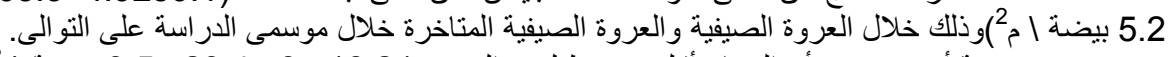

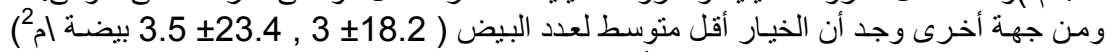

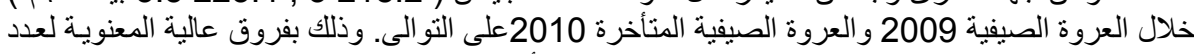

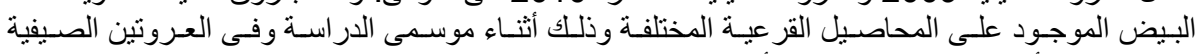

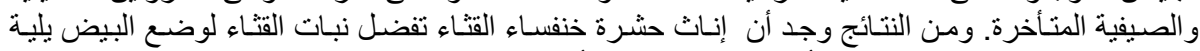

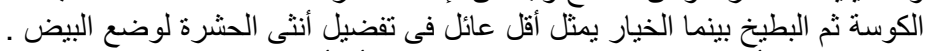

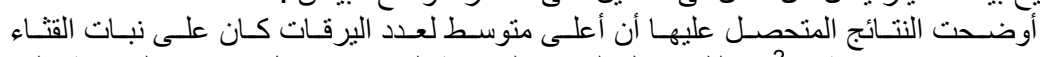

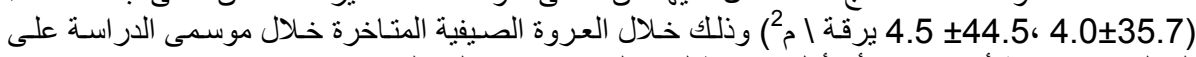

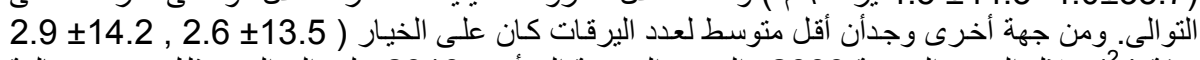

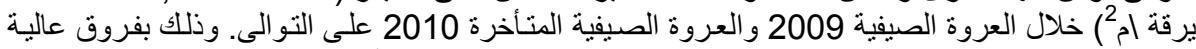

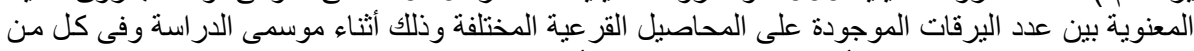

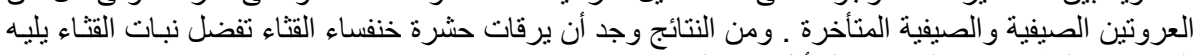

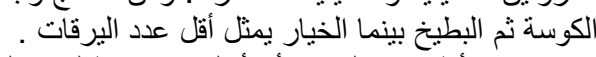

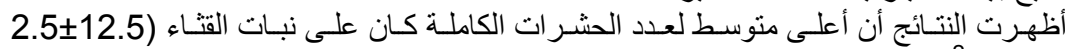

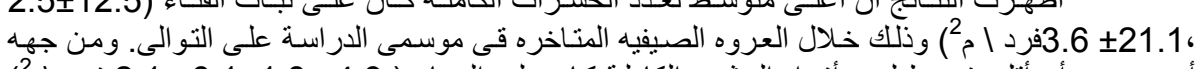

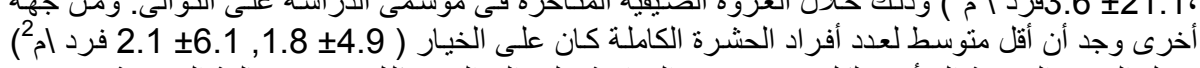

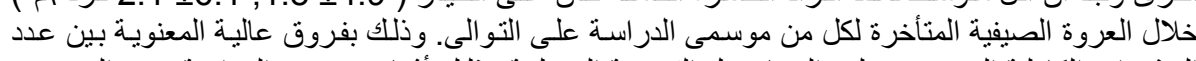

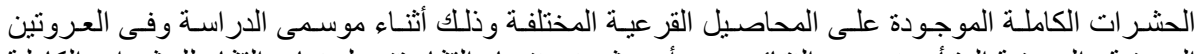

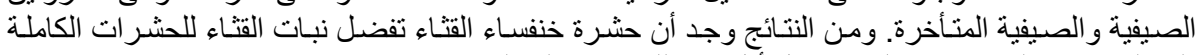

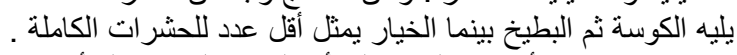

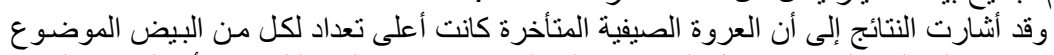

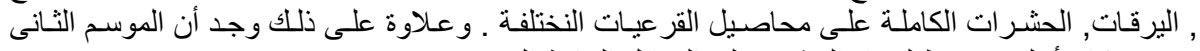
2010 كان أعلى متوسط لتعداد الحشرة على العو ائل النباتية المختبرة.

كلية الزراعة - جامعة المنصورة مركز البحوث الزراعة جامعة الزية

$$
\text { قام بتحكيم البحث }
$$

أ.د / أبد / عبد البديع عبد الحميد غانم أ.د / أد / عحمود السيد النجار 